\title{
Fragments of Human Life and Psycho Analysis of Indianans - A Reading of Salman Rushdie's Midnight's Children
}

\author{
Aungston J, Karthikh R
}

Assistant Professor, Panimalar Engineering College, Chennai, India

\begin{abstract}
This paper scrutinizes the reality of human life as an indispensable struggle to establish the self-identity of the Indian in the post-independent period from the perspective of Salman Rushdie. It probes onto the ways in which Saleem, the protagonist of the novel struggles in his life as illustrating the humanity of Indianness in his period. The paper is divided into three categories for discussion. The First category tells about "Amnesiac Nation" that deals with the emotional integration of Saleem's family which echoes the fervour of the country and it portrays the important downfalls by the country as well as the hero, where the both are suffered by Amnesia.

The second category tells about "Alienation" which explores the stage of Indians when they were alienated. By Saleem's experience of alienation, the author concerned with an unimpassioned portrayal of the problem of alienation. The third and final category tells about "Fragments of identity" that brings out the different identities in the children of one mother India. Saleem's fragments and appearance are taken as the instance to portray this. The paper sums up with the findings about the originality of the human psyche. It thus demonstrates that fragments of different identity and Indianness. Not only, it has presented its age and culture but also about its values. Keywords- Human Life, Psycho, Salman Rushdie, Midnight's Children.
\end{abstract}

\section{Amnesiac Nation}

"Cloven writer produced by migration, inhabiting and addressing worlds, the east and the west, the world of his mother country and that of his adopted country, belonging wholly to neither one nor the other." (Goonetilleke)

Amnesia is a deficit in memory caused by brain damage, disease, or psychological trauma. Essentially, amnesia is loss of memory. The memory can be either wholly or partially lost due to the extent of damage that was caused. It is the inability to retrieve information that was acquired before a particular date, usually the date of an accident or operation what is mentioned in this novel by the heroic character Saleem Sinai. In some cases the memory loss can extend back decades, while in others the person may lose only a few months of memory. Salman Rushdie stated about his novel "Midnight's children", "It seems to me that everything in this book has had to do with politics and with the relationship of the individuals and history" (Pathak 154). Salman Rushdie's "Midnight's Children" proposes a reflection on the struggles behind the project of Indian consolidation. A style of conscious mockery through the major part of the book, it raises deeply disturbing questions regarding not only our society under the colonial rule but also the institutions and values it has spawned, the cultural patterns, the hierarchies of power that have raised and which now threaten the survival of the country. A horrifying vision is described in the novel as a scathing attack on those who are responsible for literally castrating the country and thus destroying its culture and future. The history of the sub-continent from 1915 to 1979, it is inextricably interwoven with that of Saleem the hero and his family. The major events in their lives coincide with significant dates in the history of the freedom movement and post-independence India, Pakistan and Bangladesh. In the novel, Saleem calls himself, "handcuffed to history" (11).

As a classic fiction on colonial and post-colonial history of India and after partition the novel fabulates and refashions the authenticated and sanctioned annals of a new born Nation. The allegory of Nation are affirmed and put into question only to subvert the myths of nationalism. Saleem represents Postcolonial India geographically and politically. His face resembles the map of India.

Rushdie expressed the ugly, lonely and mutilated creature in the post-independent nation that fulfills the expectation of the readers. While discussing what kind of nation is this that he supposed to mirror in the novel? It is a 
nation of myths with a new myth which forgot entirely about the old. The new myth is entered to the country is about to be celebrated on it independence. As Rushdie points out:

A nation which had never previously existed was about to win its freedom, catapulting us into a world. India the new myth, a collective fiction in which anything was possible, a fable rivalled by the two other mighty fantasies: money and God. (111)

Along with the gift of democracy, their inherited religious, caste, class, provincial and religious rivalries degenerate in the midnight children's conference. Saleem aptly calls it the parliament of half-grown brats, yet it is this very babel of voices which misses when the family immigrates to Pakistan. His blocked sinuses had bestowed on him the miraculous power of a human who can able to move into anyone's consciousness and communicate at with the midnight Children, which contain the multiplicity and teemingness of India in himself. In Pakistan, and in later India during the emergency, he is condemned to silence. The off-springs of the midnight of independence are a threat to dictatorial forces. As long as they submitted to the statues with the resigned belief of what cannot be cure that must be endured. So they were tolerated, but daring to revolt and attempting to find a purpose for their one thousand and one talents, possibilities and magical gifts. They pose a great threat to the establishment. The narration of the story between him and the country has gone for thirty years. The history which is considered as an act of love at the end, when he is able to include all his memories, dreams and ideas back. As Saleem says, "I am able to include memories, dreams, and ideas. Thirty years stand waiting to be unleashed upon an amnesiac nation" (443).

\section{Alienation}

Alienation is the systemic result of living in a socially stratified society, because being a mechanistic part of a social class alienates a person from his and her humanity.

In a spiritual philosophical sense, Rushdie considers the condition of exile as the basic the basic metaphor for modernity and even for the human condition itself and himself as occupying prime position to explore such a metaphor. For Rushdie, such a condition of exile is symbolic of Post-Enlightenment relativism and disillusionment, and his particular background has produced in him a state of mind where issues of alienation, identity and belonging are central. Hence, he considers himself in a position to speak with authority on behalf of the postmodern condition.
Saleem assumes upon himself the self-styled role of prophet, which may be a highly question able is sue. But one thing is certain; he has to lead the life of a social outcast. Throughout his life, he remains of a better life. He is ultimately flattened like the ancestral spittoon by forces beyond his control. Saleem confesses to have developed uneasy symptoms of schizophrenia. He says: "I admit openly I have not been myself of late. I have been a Buddha, and a basketed ghost. And would-be-saviour of the nation, rushing down blind alleys with considerable problems of reality" (520). He is nevertheless obsessed with the purpose of life. It was at a very age he became perplexed by meaning. He became afraid that everything was wrong that his much trumpeted existence might turn out to be utterly useless, void and without the shred of a purpose. Saleem variegated experiences are such that they only make him always confused about being good. He neither acquires a philosophical wisdom, like that of a prophet, nor does he understand the commonsense solution to life's problems. In this respect, Saleem's lot is typical of all alienated persons. This confusion turns out to be the besetting sin of Saleem's sensibility and conduct. As he himself admits, "I am so far gone, in my desperate need for meaning that I am prepared to distort everything. In my confusion I can't judge" (198). Saleem betrays at times characteristics of anti-hero. He had acquired a miraculous gift but to conceal his talents. This is not because of any humility but because of an abysmal self-estrangement. He is fully aware of his problems and plights, misfortunes and discordances, so typical of a rootless person. This is how he looks at himself finally: "I'm tearing myself apart, can't even agree with myself, talking arguing like a wild fellow, cracking up, memory going, yes, memory plunging into chasms and being swallowed by the dark" (503). This is the height of self-alienation. This represents, in brief, the plight of Saleem's clock-ridden, crime-stained birth. Rushdie's alienated characters convey, in varying degrees, a sense of unhappy frustration resulting mainly from their social menu. He has ruthlessly presented their social tragedy and psychological trauma. He wields irony and satire with competence. And his command over language enables him to depict crucial events and character-traits without melodrama. The author is concerned with an unimpassioned portrayal of the problem of alienation and does not bother to suggest any solution to it. In this novel, he expressed how characters faced the human problems in the environment. These rootless persons are simply broken promises, made to be broken.

\section{Fragments of Identity}


In Midnight's Children, the novel invites a picaresque narrative, a political allegory, a topical satire, a comic extravagance, a surrealist fantasy and an experiment in form and style with elements drawn from Rabelais, Joyce and Gunter Grass. These two facts are absorbing interests in the novel. The study of the central theme unifies all these as the theme of identity. Both actions and character repeatedly emphasize this theme and show the numerous ways in which identity is made suffer. Identity in the novel is shown as mistaken and confused, fractured and fragmented. It is suggested to oblivion and dwarfed and reduced to animal level. Furthermore, since heredity is inevitably an essential element in identity. Identity in the novel is repeated from generation to generation in a narrative manner. It is opened with the grandfather and closes with the grandson.

As the Centre, the main personality Saleem stands as the protagonist whose life and career illustrate the entire process in various aspects. His birth on the stroke of the midnight on the day which marks the great divide between colonial and independent India is itself symptomatic of his identity crisis. His family name too underscores the element of instability in his entire clan.

As heputs it, "Our names contain our fates, we are also the victims of our titles" (304). He then tells how his family name 'Sinai' contains, among other elements, 'Sin the moon' and there could not be a better symbol of the instability of his character than waxing and waning like the moon. Sinai contains Ibn Sina, master magician, Sufi adept; and also Sin the moon, the ancient god of Hadramaut, his powers of action at a distance upon the tides of the world. But $\mathrm{Sin}$ is also the letter ' $\mathrm{S}$ ', as sinuous as a snake; serpents lie coiled within the name.

Saleem's family name, Sinai, represents, among many things, "Ibn Sina", a religious figure hailed as one of the foremost philosophers of Islamic tradition.His first name 'Saleem', etymologically, means "simple" and "straightforward". Consider Saleem's personal appearance points to the general lack of strength in his character. His name, through its beginning letter, also means the snake, a typically Christian symbol of sin, and destruction. When it is transliterated, Sinai is also the place of revelation and, when signifying neither of the above, it is simply, and more provocatively, "the desert." The multiple meanings of his name suggest a communication and unification of different social, cultural and spiritual traditions. As he grows up, Saleem is subjected to a series of personal mutilations. The way he faced accidents itself result the new identity for himself.

First of all, when he claims that he has started hearing voices of others, his father, shocked of this heresy, fetches him a mighty blow on the side of his head, which makes him permanently deaf in his left ear. This is followed by the accident with Evie's bicycle result of which Saleem is suddenly able to hear the voice of other midnight's children, who start sending signals to them. Soon after, there is another accident in Social School. This time Saleem loses the top third of his middle-finger. During the IndoPakistan War of 1965, he is injured in bomb-blast, hit by his mother's silver spittoon which crashes on the back of his head.

As a result of this, he loses his memory completely. The external symbol of this is that his body has gone fully numb, the only sense active being his sense of smell. This numbness is so total even when his fellowsoldiers subject him to a strong electric current, his body registers no sensation. They began to call him"buddha". During the Bangladesh war, Saleem has another accident; a snake bite in the Sunderbans restores his memory.

These several accidents and assaults and their consequence indicate the stress and strains which disfigure the protagonist's identity throughout his life.The idea that he is fated never to know peace and stability is symbolically suggested by the fact that when the house in Pakistan is being constructed. But the house is destroyed by a bomb during the war and the hero has to migrate to India. That Saleem is thus battered and bruised his entire career is also perhaps his nemesis for being born with an identity crisis. He is actually the illegitimate son of a Hindu woman Vanita and an Englishman William Methwold. At birth he is exchanged by the same time in the adjoining room of the maternity home by Mary Pereira. Her own private revolutionary act is for giving a poor baby a life of privilege. He is destined to have more than two mothers and several fathers a well. As he observes: "I have had more mothers than most mothers have children" (243). When his parentage is discovered, he is entrusted to the care of his childless aunt Pia. Thus apart from his real mother Vanita and his putative one Amina, Mary Pereira, the midwife, is also a kind of mother to him since he baby-swapping. To make matters still more complicated, his putative mother dreams a strange dream on the night after he is born.

One serious result of Saleem's identity crisis is the sexual trauma it generates. He becomes conscious of his incestuous passion for his sister Jamila when Tai Bibi reveals the terrible secret to him. Even while trying a magical charm to make Jamila fall in love with him and attempting to explain to her that this was no sin, since they were not really brother and sister. Saleem is conscious of the fact that no amount of rationalizing can break the tie that bound them together all these years. The timing of his 
Saleem to an even more difficult fate by giving his personal identity a larger dimension which brings in its own revenge, as time passes. Nehru states that he is the ancient face of India. Saleem thus becomes conscious of his larger identity quite early in his life. He is linked to his tory both literally and metaphorically. This consciousness confers strange powers on him. He develops the ability to pry into the thought-processes of other people and establishes connection with the other midnight's children. But these new powers make only for greater ordeals and misery, instead of producing happy results.

The protagonist's identity-crisis is partly anticipated in the lives of his ancestors. The motif of fragmentation is prominent in the life of his grandfather Aadam Aziz also. When Dr Aziz is asked to treat Naseem, the girl who is soon to become his wife, owing to purdah restrictions only the ailing part of the patient's body is revealed to him, through a perforated sheet held up by two lady wrestlers.

The same motif is also seen to operate in the married life of Aadam's daughter and Saleem's mother Amina. She had been married earlier to Nadir Khan, who had been divorced by him when it was discovered that he was impotent. "So gradually Doctor Aziz came to have a picture of Naseem in his mind, a badly-fitting collage of her severally-inspected parts. This phantasm of a partitioned woman began to haunt him, and not only in his dreams" (25).

After her marriage to Ahmed Sinai, Amina is still unable to forget Nadir Khan. She decides that she must train herself to love her new husband. This indicates the pathetic situation of the women in the Indian Society. To do this she divided him, mentally, into every single one of his component parts, physical as well as behavioral. Each day she selected one fragment of Ahmed Sinai, and concentrated her entire being upon it until it became wholly familiar; until she felt fondness rising up within her and becoming and, finally she began to love him. The perforated sheet motif reappears in the third generation too, in the career of Amina's daughter Jamila, who becomes a famous singer. Her parents realize that her gift is too extraordinary to keep to them but they hesitate to allow her to be put on the stage in full public view. The sour grapes eaten by Saleem's forebears also set the teeth of his son on edge. The fragmentation syndrome affects the fourth generation too. Like Saleem, his son Aadam has two fathers, Siva being his real father, since Saleem is impotent.

The mythological, cultural and spiritual significance of Saleem's name, for example, illustrates, through its cross cultural references of mythology and symbolism, a conscious unification of Eastern and Western influences. The conscious integration, recognition and acceptance of his identities illustrate Saleem's fullness and wholeness as a character. He embodies all the cultural traditions of Indian society, fully accepting them as part of who he is, individually and collectively. Saleem draws upon each identity in an attempt to help him "understand current problems" nationally and personally. Saleem's quest for purification illustrates a recreation of his primary Self. With new memories and new experiences Saleem can throw away, if even momentarily, the past roots of filthy dirty love of whores, of needing to be loved and growing too fast. His "I" calls to be restored to innocence and purity thus transforming him into, what his fellow soldier calls, "the Buddha" (397).

\section{Self-Recreation}

Saleem's self-recreation achieves completion, encompassing, along with his many other identities, the identity of "the Buddha": "I was rejoined to the past, jolted into unity by snake pois on, and it began to pour out through the Buddha's lips" (419). Fragments of human life and psycho analysis of Indianness is been illustrated in the novel form the beginning till the end. In addition to the narrative and physical fragmentation, India itself fragmented by its too many faces. Different types of human living aspects share the new forms of cultural identity that reflects the constant divisions. To illustrate the different type of identity lived in the period of pre and postindependence India, author expressed the varied textures, overlapping mythologies, fabulous fantasies and harsh realities of Indians. It is so significant that studying the Indian traditions and cultures before the different fragments of human life in Indian soil. With the author's tremendous skill at creating regional atmosphere, the novel is somewhat like kaleidoscopic show of the old and the new of the country. Saleem's character itself represents the various characterization and culturalism in India.

The peculiar narrative structure of Midnight's Children poses questions regarding the processes of selfknowledge, epistemology, and hermeneutics within a relative universe devoid of any Prime Mover or ultimate referent. These issues are deeply related and clearly express Rushdie's fundamentally anti-religious and anti-traditional attitude to epistemology, ontology and politics. Yet it will be seen that even in this climate, but on a deeper level, the story of Midnight's Children does not escape a certain balance of form or integratedstructure. There is a baseline of objective order residing beneath the superficial chaos and epistemological despair of Rushdie's narrative, a hint 
of ultimate principles and structures that somewhat redeems the corrosive relativism of his imaginary worlds.

\section{REFERENCES}

[1] Rushdie, Salman. Midnight's Children. London: Picador, 1981. Print.

[2] Chaterjee, Partha. The Nation and its Fragments: Colonial and PostcolonialHistories. Princeton: Princeton UP, 1993. Print.

[3] Clark, Roger. Stranger Gods: Salman Rushdie's other worlds. Montreal: McGi Queen's UP, 2001. Print.

[4] Mattoo, Neerja. "Indianness in midnight's children: Rushdie's view of an Amnesiac nation." The Indian novel in English: Essays in criticism. Ravi Nandan and R.K. Sinha, eds. Ranchi: Ankit Publishers, 1987. 6376. Print.

[5] Pathak, R.S. "Salman Rushdie's Treatment of Alienation." Indian fiction in English: Problems and Promises. New Delhi: Northern Book Centre,1990. 155-169. Print.

[6] Roberts, Jane "Identity Crisis." Yahoo. N.p., n.d. Web. 09 March 2014.

[7] Rushdie, Salman. Imaginary Homelands: Essays and Criticism 1981-1991.

[8] London: Granta Books, 1991. Print. 